\title{
Scotland's Coastal and Marine Policy: from voluntary partnerships through devolution to a Marine Act.
}

\author{
Tim Stojanovic, Scottish Oceans Institute and Sustainability Institute, School of Geography \\ and Geoscience, University of St.Andrews, Timothy.Stojanovic@st-andrews.ac.uk
}

\begin{abstract}
This paper presents an analysis of marine and coastal policy in Scotland from the period of the 1990 s with the launch of voluntary partnerships, through the devolution of the 2000s up to the development of a Marine Act in 2010. Scotland has a coastline of c.11 $000 \mathrm{~km}$ and vast bordering offshore seas with significant sectors of the marine economy in a growth phase and coastal communities reliant on marine activities, as well as wilderness areas with high landscape and conservation value. The analysis considers some of the key drivers which have led to increased consideration of sustainability for coasts and seas. The paper describes a new regime within the Marine Act and focuses on the arrangements for marine planning and management. The conclusion summarizes the overall evolution of the regime for governance and examines some of the key challenges which must be met, if management of the marine and coastal environment for Scotland and the UK is to be truly integrated, participatory, and ecologically sustainable.
\end{abstract}

\section{Keywords: Policy, UK, Scotland, Coast, Marine, Management, Planning, Governance}

\section{History of Marine and Coastal Policy Development}

Policymaking for coasts and seas relates to a great variety of endeavours, including: the development of marine resources and sectors; the development of coastal settlements; protection and conservation of species, habitats, seascapes and heritage; environmental management, hazard management related issues such as flooding and erosion, and social objectives such as access to the coast. For Scotland, the institutions responsible for setting such policy have evolved markedly during the period 1990-2010, especially with the process of devolution. NGOs and businesses also have considerable roles in influencing policy and monitoring the outcomes of policies.

The background to development of policy is the human activities occurring in the marine environment and the increasing emphasis on sustainability as a guiding principle. The coast has long been a focus for settlement, with patterns of coastal development which can be traced over a century ago. In the modern period up to the 1950s the Scottish seas provided a resource basis which supported major maritime industrial development, particularly in the fishing, shipping and shipbuilding sectors. Some of these sectors declined markedly with economic restructuring post World War Two (Phillips, 2005). The development of oil and gas fields in the North Sea from the period of the mid 1960s led to significant offshore and coastal development on East coast of Scotland (Pinder 2005). The development of aquaculture in the late 1970s followed on from the domestication of Atlantic Salmon. During the 1990s salmon and shellfish farming, focused along the north and west coasts, grew to account for a significant proportion of fish production by tonnage and value (Coull, 1999). At the present time, marine renewable energy technologies are in a phase of development and future technologies are required to deal with impacts of climate change (Side and Jowitt, 2002). The marine recreation and tourism sector is also of key importance to many coastal economies, with an expanding range of activities (Atlantic Coast Project, 2004). 
Policymaking engages with development by exploring how to enable or constrain such activities, to deal with the trade-offs between different forms of development and their impacts on the environment, and a more strategic level, to deliver sustainable outcomes. The choices made at a strategic level, steer investments and activities, and set agendas (to varying degrees). In modern government, the development of policy tends to be a deliberative process, where government consults extensively with stakeholders throughout the process.

Historically, it is somewhat artificial to talk of marine and coastal policy per se., as policy relating to coasts and seas has been developed by a myriad of government departments and agencies, sometimes with limited coordination. The need for an integrated approach to the planning and management of oceans, coasts and islands was highlighted in Chapter 17 of Agenda 21 (UNCED, 1992) and from this time onwards has been increasingly promoted at an international level. The limitations of a sectoral approach were outlined in a Review of Coastal Zone Protection and Planning by the UK House of Commons Select Committee on the Environment in 1992 (House of Commons Environment Select Committee, 1992) which suggested many reforms to rationalise institutional and legislative frameworks. However, at this time the UK government and Scottish Office resisted the call for a new framework, but promoted voluntary collaboration as the way forward (Scottish Office, 1996).

\section{Voluntary Partnerships}

Table 1. Marine and Coastal Initiatives in Scotland (sub-national)

\begin{tabular}{|c|c|c|c|}
\hline Coastal Partnership & $\begin{array}{l}\text { Founding } \\
\text { Initiative }\end{array}$ & $\begin{array}{l}\text { Year } \\
\text { Founded }\end{array}$ & $\begin{array}{l}\text { Active in } \\
\text { 2010? }\end{array}$ \\
\hline $\begin{array}{l}\text { Orkney Marine and Coastal } \\
\text { Forum }\end{array}$ & Orkney Council & 1992 & No \\
\hline $\begin{array}{lll}\text { Cromarty } & \text { Firth } & \text { Liaison } \\
\text { Group } & & \end{array}$ & $\begin{array}{l}\text { Highland } \\
\text { Council }\end{array}$ & 1992 & No \\
\hline Forth Estuary Forum & Focus on Firths & 1993 & Yes \\
\hline Firth of Clyde Forum & Focus on Firths & 1993 & Yes \\
\hline Solway Firth Partnership & Focus on Firths & 1994 & Yes \\
\hline $\begin{array}{l}\text { Fair Isle Marin Environment } \\
\text { \&Tourism Initiative. }\end{array}$ & Local Initiative & 1995 & Yes \\
\hline The Minch Project Forum & $\begin{array}{l}\text { SNH/Western } \\
\text { Isles Council }\end{array}$ & 1996 & No \\
\hline Moray Firth Partnership & Focus on Firths & 1996 & Yes \\
\hline Tay Estuary Forum & Focus on Firths & 1997 & Yes \\
\hline $\begin{array}{l}\text { Loch Ryan Advisory } \\
\text { Management Forum }\end{array}$ & Local Initiative & 1997 & No \\
\hline $\begin{array}{l}\text { The Minch Project-Loch } \\
\text { Torridon }\end{array}$ & $\begin{array}{l}\text { SNH/Western } \\
\text { Isles Council }\end{array}$ & 1999 & No \\
\hline
\end{tabular}




\begin{tabular}{|l|l|l|l|}
\hline Western Isles CZM Forum & $\begin{array}{l}\text { Western Isles } \\
\text { Council }\end{array}$ & 2002 & No \\
\hline $\begin{array}{l}\text { East Grampian Coastal } \\
\text { Partnership }\end{array}$ & $\begin{array}{l}\text { Aberdeen } \\
\text { Council } \\
\text { Atlantic Coast (Wester } \\
\text { Ross) Project } \\
\text { Council/Interreg }\end{array}$ & 2004 & Yes \\
\hline Shetland SSMEI & SSMEI & 2006 & Yes \\
\hline Berwickshire SSMEI & SSMEI & 2006 & Yes \\
\hline Clyde SSMEl & SSMEI & 2006 & Yes \\
\hline Sound of Mull SSMEI & SSMEI Isles & 2007 & Yes \\
\hline $\begin{array}{l}\text { Outer Hebrides Marine and } \\
\text { Coastal Partnership }\end{array}$ & $\begin{array}{l}\text { Western } \\
\text { Co. }\end{array}$ & 2007 & \\
\hline
\end{tabular}

In the absence of a statutory approach to coastal management, the focus during the early 1990s was developing coastal policy at the local level. Scottish Natural Heritage promoted the Focus on the Firths programme in 1993. This was a response to development pressures in major firths and conservation priority for estuarine ecosystems. The programme was key in establishing and supporting integrated management and planning in the Forth, Clyde, Solway, Moray and Tay estuaries, involving a variety of stakeholders. These initiatives have sought to develop integrated, placed-based management for the coast. The policies developed for each coastal area reflect the priorities at each time and place. For example, the Forth Integrated Management Strategy (FEF, 1999) includes themes such as integrated coastal defence and sustainable fisheries, whilst the Tay Estuary Management Plan (TEF, 2009) has focused on issues such as marine renewable energy development and social regeneration. The strengths of such initiatives include a holistic and participatory approach which reflects local needs (Gubbay, 2001). However, the challenges include the investment burdens of a participatory approach and the lack of resources or incentives to drive implementation (Scottish Executive Social Research, 2002a). The Scottish Coastal Forum was formed in 1996 and has played an increasing role in highlighting and supporting local efforts. Altogether 19 coastal or marine initiatives have been established in Scotland, of which 13 were still active during 2010 in some way (Table 1). Whilst the voluntary approach allows for flexibility so that these regional and local initiatives could respond to local needs, many of those involved in coordination lamented the absence of a national programme or national leadership (Stojanovic and Barker, 2008). However, some integrated policy development did begin at the national level during this period. Notably in 1997, NPPG13 Coastal Planning, was a planning policy which enshrined a presumption against development 'which does not require a coastal location' or on coasts which are 'undeveloped'. 


\section{Devolution}

The devolution settlement under the Scotland Act 1998, led to the establishment of the Scottish Executive with significant devolved responsibilities related to fishing, ports and the environment. Understandably, this has led to an increasing role for Scotland in developing coastal and marine policy, and divergent approaches from other UK countries (a process which had already begun with the Environmental Protection Act 1990) (Gubbay, 2002; Ballinger 2005). A number of policy briefs were developed, including a socio-economic scoping study of Scotland's Coast (Scottish Executive Social Research, 2002b) which highlighted the particular needs of coastal communities including deprivation on urban coasts and migration from peripheral rural coasts. The Scottish Coastal Forum was highly active in supporting policy development through deliberative processes, and with its 20 member organisations produced $A$ Strategy for Scotland's Coasts which was presented to ministers in July 2004. This strategy highlighted the need for integrated policies to deal with a range of sectoral issues such as declining fish stocks, expanding agriculture and renewable energy sectors, water quality (nitrogen enrichment) and litter, sea level rise, and increased use of inshore waters for recreation. The objectives for action stressed the overarching goal of integration and introduced the concept of spatial planning for coasts and seas. The document also gave assent to a number of principles of good practice, including stakeholder involvement, sound scientific evidence base, and a participatory approach. (Scotland was first of the UK home nations to produce a national strategy for the coast in response to chapter 4 of the EC recommendation on ICZM [COM 2002/414/EC]).

Meanwhile, in 2002 the Sustainable Seas Marine Environmental Initiative (SSMEI) had been established to review future planning regimes for the marine environment. These efforts culminated in the development of Seas the Opportunity, the first integrated national strategy for Scotland's coast and seas (Scottish Executive, 2005). Figure 1 shows the policy landscape as defined by this document. The policies included a commitment to a number of key principles, including: sustainable development; increased coordination between sectors; and assessment of cumulative impacts of development. In this sense, the strategy drew on commitments made at the UK level in Safeguarding Our Seas (DEFRA, 2002) which themselves built on emerging principles in international conventions and commitments (e.g. for the World Summit on Sustainable Development) such as the ecosystem approach, the precautionary principle, robust science, stakeholder involvement, integration and sustainable development. Seas the Opportunity also contained a timetable of outputs and outcomes to 2030. This focused on putting a management framework in place, but also included a number of defined policy goals such as: sustainable strategies for fish stocks; the reduction of flood risk; achievement of good ecological status for marine waters; reduction in eutrophication incidents and emissions of hazardous and radioactive substances; increase in protected areas; halting loss of biodiversity; and increase in renewable energy output. Consultations for the Scottish strategy raised the proposal for a marine act and provisions for marine protected areas, marine planning and a marine agency, but the government stopped short of this action at this point. Instead in November 2005, an Advisory Group on Marine and Coastal Strategy (AGMACS) was set up with ministerial leadership to take forward this work. About 30 representatives from industry, NGOs, regulatory agencies and individual experts were tasked with the work. The outcomes, documented in Recommendations a Marine and Coastal Strategy (Scottish Executive, 2007), included proposals for marine science coordination, a national marine management organisation, regional coastal policies, a 3-tier marine planning system and a system of marine protected areas. 


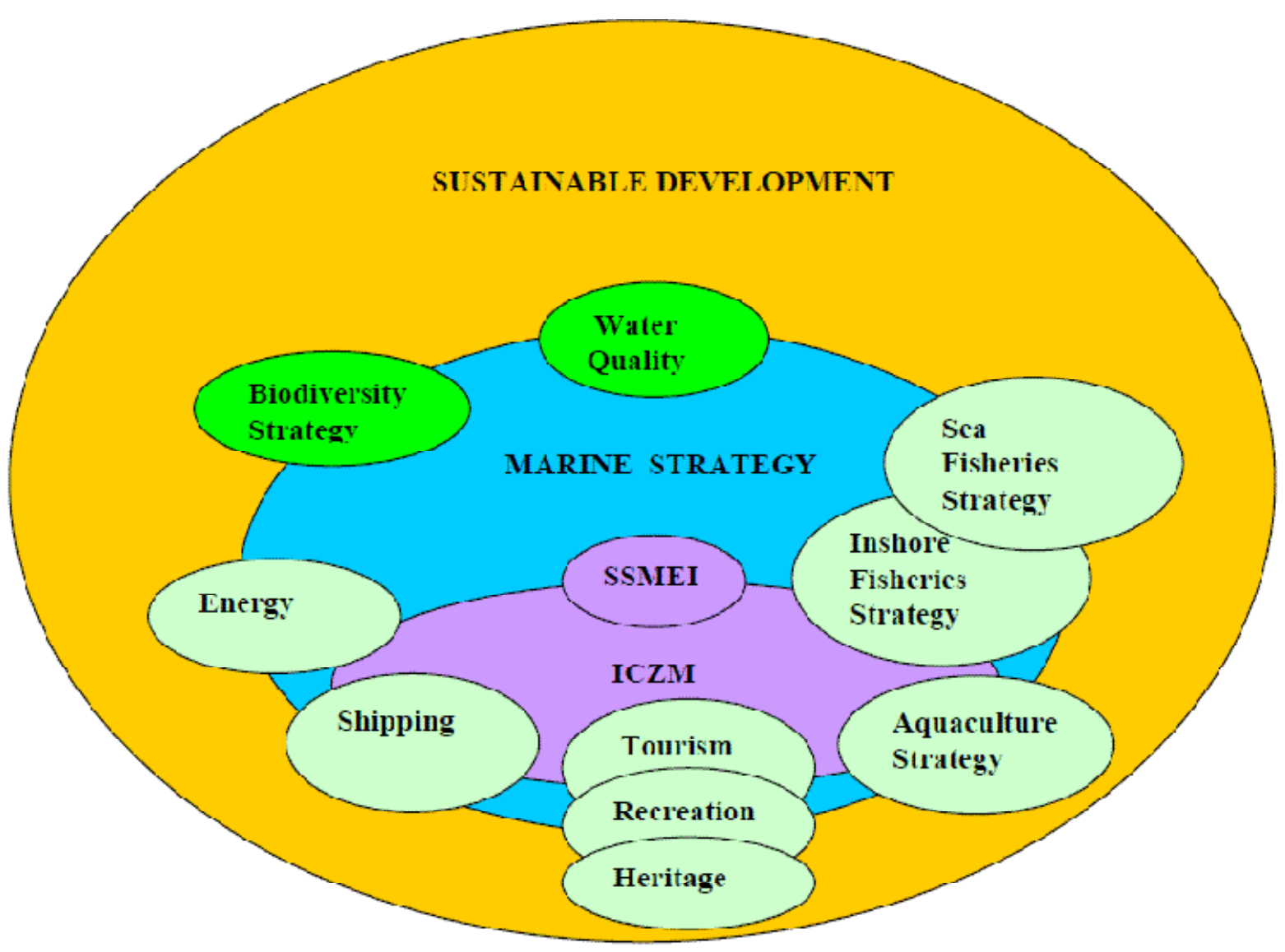

Figure 1 Policy Framework for Scotland's Coasts and Seas in 2005 Source: Scottish Executive (2005, p.28)

Table 2: Sectoral Policies

\begin{tabular}{|l|l|l|}
\hline Policy Field & Competence & Selected Scottish Policy Documents (2000-2010) \\
\hline Ports & Scotland/UK & National Transport Strategy (2006) \\
\hline Shipping & International/UK & - \\
\hline Navigation & International & - \\
\hline Military & UK & - \\
\hline Communications & UK & - \\
\hline Sea Fisheries & European & Sustainable Framework for Scottish Sea Fisheries (2005) \\
\hline Inshore Fisheries & Scotland & Strategic Framework for Inshore Fisheries in Scotland(2005) \\
\hline
\end{tabular}




\begin{tabular}{|c|c|c|}
\hline Aquaculture & Scotland & $\begin{array}{l}\text { Strategic Framework for Scottish Aquaculture (2003) Scottish } \\
\text { Aquaculture: a fresh start (2008) }\end{array}$ \\
\hline Renewable Energy & Scotland/UK & \multirow[t]{2}{*}{$\begin{array}{l}\text { Energy Industries Strategy (2005-10) A strategic } \\
\text { framework for Scotland's Energy Sectors. }\end{array}$} \\
\hline Oil and Gas & UK & \\
\hline Natural Heritage & Scotland/UK & Scottish Biodiversity Strategy (2004) \\
\hline $\begin{array}{l}\text { Cultural Heritage } \\
\text { and Archaeology }\end{array}$ & Scotland/UK & $\begin{array}{l}\text { Scottish Historic Environmental Policy: the marine } \\
\text { environment (2008) }\end{array}$ \\
\hline $\begin{array}{l}\text { Tourism and } \\
\text { Recreation }\end{array}$ & Scotland & $\begin{array}{l}\text { Scottish Tourism: the next decade- A Tourism Framework } \\
\text { for Change (2006) }\end{array}$ \\
\hline $\begin{array}{l}\text { Waste Management } \\
\text { and Water Quality }\end{array}$ & Scotland & $\begin{array}{l}\text { Scotland's Bathing Waters: a Strategy for Improvement } \\
\text { (2002) } \\
\text { Bathing Water Strategy (2006) } \\
\text { Scottish River Basin Management Plan (2009) }\end{array}$ \\
\hline $\begin{array}{l}\text { Economic } \\
\text { Development }\end{array}$ & Scotland/UK & $\begin{array}{l}\text { A Framework Strategy for Scottish Agriculture } \\
\text { Enterprise Strategy: a Smart Successful Scotland } \\
\text { Going for Green Growth - a Green Jobs Strategy for } \\
\text { Scotland } \\
\text { National Planning Framework } 2\end{array}$ \\
\hline
\end{tabular}

Sources: Scottish Government (2008, p.22)

Concurrently with the initiatives described above, a number of sectoral marine and coastal policies have been developed by the devolved administration (see Table 2). The fields of policy development vary according to the competencies held by the government - most relate the territorial sea $(<12 \mathrm{~nm}$ offshore). However, this continues to evolve. For example, the Strategic Framework for Inshore Fisheries in Scotland (2005) has developed a locally-driven management system, with voluntary Inshore Fisheries Groups setting up management plans in order to deal with issues such as stock conservation and intra-fisheries conflicts. This approach is divergent from fisheries management arrangements in England and Wales (Scottish Executive, 2005; Phillipson and Symes, 2010). Amongst other goals, in June 2005, the Minister for Environment and Rural Development announced the intention to create Scotland's first coastal and marine national park by 2008. Five locations were put forward in a consultation, however potential impacts on fishing, aquaculture and other livelihoods including agricultureii led to the proposals being sidelined. This example highlights how policymaking as a deliberative process involves political constituencies and trade-offs between different interest groups. These trade offs will not always result in 'wins' for all groups concerned. In this case it was not possible to achieve the goal of strategic policy, aiming to integrate cross-sectoral interests.

\section{A Marine Act for Scotland}

A change in government administration in May 2007 (and a renaming of the 'Scottish Executive' to 'Scottish Government') occurred at a time of increasing focus on the development of new marine legislation worldwide, in Europe and the UK. 'Marine Scotland' was setup as part of the 
core Scottish government in 2009 as the lead marine management organisation (bringing together the previous Scottish Government Marine Directorate, the Fisheries Research Services [now Marine Scotland Science] and the Scottish Fisheries Protection Agency [now Marine Scotland Compliance]). Since this time, a 'Marine Strategy Forum' involving a variety of stakeholder organisations has overseen the work of Marine Scotland. Phases 2 and 3 of SSMEI initiative, between 2005-10, have led to the development of four pilot projects in Berwickshire at St.Abbs Head, the Firth of Clyde, Sound of Mull and Shetland (Table 1). Amongst other things, these projects have developed practical approaches for the development of marine spatial plans, and draft spatial plans with accompanying Strategic Environmental Assessments have been produced for three areas.

Closely following on from the UK Marine and Coastal Access Bill, the Marine (Scotland) Bill was introduced to the Scottish Parliament on $29^{\text {th }}$ April 2009. Through the parliamentary debates and committee processes, various policy issues have been contended, including expanding aquaculture development within the territorial sea, and the role of local government planning vs. central government in steering these developments. In essence, the proposals in the Marine Act provide a framework for managing competing demands on marine space through: (1) A National Marine Plan (2) A reformed, simpler licensing system (3) New powers to select and manage Marine Protected Areas (MPAs) for biodiversity and historic assets (4) Improved protection for seals, including a comprehensive license system and tougher penalties. The Act received royal assent in March 2010 and its powers are complementary to the provisions of the UK Marine and Coastal Access Act 2009, including further devolution of powers relating to marine planning and nature conservation in offshore waters outside 12 nautical miles. At the time of writing, work is focusing on setting of socioeconomic and marine ecosystem objectives (Marine Scotland 2010; Saunders and Scott, 2010) and the development of a national marine plan. These will be followed by plans developed through Regional Marine Planning Partnerships, building on phase 3 SSMEI draft marine spatial plans.

\section{Drivers for Sustainability}

A Marine (Scotland) Act 2010 marks somewhat of a watershed in marine and coastal policy development. A range of drivers have brought this about, not least the needs of different sectors. The narrow views which predominated sectoral policymaking have become outmoded and it has been accepted by the vast majority of stakeholders that this kind of approach is inefficient. The increasing spatial complexity of human activities has created a need for an integrated approach. Arguably the demands of another 'layer' of development, in the form of offshore renewable energy, have convinced government to move beyond the voluntary approach which predominated in the 1990s phase. Supranational (EU) and international drivers for good governance, and in specific policy fields, have also been influential on policy development (Ballinger and Stojanovic, 2009). In the whole period under consideration, the role of European marine and environmental policy has remained strong. Many Scottish policy frameworks have been driven by EC legislation including the Habitats Directive (EC97/43/EEC) Water Framework Directive (200/60/EC), and most recently the Marine Strategy Framework Directive (2008/56/EC) which should be transposed to national legislation by 2010 , and European maritime policy (COM 2007/575). The UK Marine

Strategy and UK and Scottish commitments to sustainable development also seem to have informed the direction of policy development- at least on paper- with commitments to sustainability 


\section{Challenges for Integration}

Now that new Scottish marine legislation and institutional arrangements are in place, and a range of sectoral policies have been developed, the challenge will be to implement this and develop a working system of marine planning. Drawing on experiences in the development of terrestrial planning systems, the new system is likely to take a number of years before it reaches maturity, in terms of running through the first cycle of plan making, and developing the competence of marine professionals to do marine planning. One of the challenges will be to coordinate marine planning with terrestrial planning (Smith et al. 2010) especially since many marine developments have significant requirements for landfall of goods or infrastructure, and there are implications of marine developments for terrestrial communities. Another key challenge will be to achieve integration between the different objectives, managing competing demands whilst taking an ecosystem approach.iii In this sense, the political usage of the language of 'sustainable development' is hardly unsurprising with its assent to both development and conservation agendas. Nevertheless, sustainability offers the potential for a new guiding vision- if this is to go beyond rhetoric it must be integrated into policymaking and supported by scientific and monitoring systems (Baxter et al. 2008). The development of a system of marine protected areas represents a significant conservation policy which NGOs have campaigned hard and lobbied for, which will offer some protection against over-exploitation. However, in the Scottish context at the present time the sustainable economic growth agenda is a priority. Scotland's seas and their gateway coasts present a development frontier, with expanding controls for government and expanding sectors such as marine renewables. Exactly how this works out, will depend on the geographical expressions of marine and coastal policies, which brings us back to reconsideration of the work of regional and local partnerships; the process of creating regional marine/coastal spatial plans will have to engage with the question of appropriate zones for development including fisheries, aquaculture, energy and marine recreation.

\section{References}

Atlantic Coast Project, 2004 Tourism and Recreation Topic Paper. Highland Council: Ullapool.

Ballinger, R. and Stojanovic, T. 2010. Policy development and the estuary environment: A Severn Estuary case study. Marine Pollution Bulletin, 61, 132-145

Ballinger, R. C. 2005. A sea change at the coast: the contemporary context and future prospects of integrated coastal management in the UK. In "Managing Britain's Marine and Coastal Environment". H. D. Smith and J. S. Potts. Abingdon, Routledge and the National Maritime Museum.

Baxter, J.M. Boyd, I.L. Cox, M. Cunningham, L. Holmes, P. and Moffat, C.F. 2008. Scotland's Seas: Towards Understanding their State. Fisheries Research Services, Aberdeen. Coull, J.R. 1999 Changing balance of fish production in Scotland Marine Policy 23 347-358

Department for Environment Food and Rural Affairs (DEFRA) (2002). Safeguarding Our SeasA Strategy for the Conservation and Sustainable Development of our Marine Environment. London, DEFRA.

Forth Estuary Forum, 1999. Forth Integrated Management Strategy. FEF: Rosyth. 
Gubbay, S 2001 The Role of Scottish Local Initiatives in Implementing the Principles of IntegratedCoastal Zone Management.

Gubbay, S. 2002. Just coasting. An assessment of the commitment of the devolved administrations and the English regions to Integrated Coastal Management. A report to the Wildlife Trusts and WWF. Godalming, WWF-UK. Original Research 8

House of Commons Environment Select Committee, 1992. Coastal Zone Protection and Planning HMSO London

Marine Scotland 2010. Report on Social and Economic Objectives for a Scottish Marine Plan A Report Prepared by Scottish Association for Marine Science. Scottish Government: Edinburgh,

Phillips J 2005 Oceanspan: Deindustrialisation and devolution in Scotland, c. 1960-1974 Scottish Historical Review 84 63-84

Phillipson, J. and Symes, D. 2010. Recontextualising inshore fisheries: The changing face of British inshore fisheries management. Marine Policy, 34 (6) 1207-1214.

Pinder, D.A. 2005. Oil and Gas from UK Waters: resources, technologies, corporate attitude and government. In "Managing Britain's Marine and Coastal Environment". H. D. Smith and J. S. Potts. Abingdon, Routledge and the National Maritime Museum.

Saunders G. and Scott M.M. 2010. Scottish marine ecosystem objectives: Scoping study. Scottish Natural Heritage Commissioned Report No. 341.

Scottish Executive Social Research, 2002a. Assessment of the effectiveness of local coastal management partnerships as a delivery mechanism for integrated coastal zone management. Scottish Executive, Edinburgh

Scottish Executive Social Research, 2002b. Scottish Coastal Socio-Economic Scoping Study. The Stationary Office, Edinburgh.

Scottish Executive, 2005. Seas the Opportunity- A Strategy For The Long-Term Sustainability Of Scotland's Coasts And Seas. Scottish Executive, Edinburgh.

Scottish Executive, 2007. Recommendations of the Advisory Group on Marine and Coastal Strategy: A follow up to the Seas the Opportunity: A Strategy for the Long Term Sustainability of Scotland's Coasts and Seas. Scottish Executive, Edinburgh.

Scottish Government, 2008. Sustainable Seas for All. The Scottish Government, Edinburgh.

Scottish Office, 1996. Scotland's Coast- a discussion paper. HMSO, Edinburgh.

Side, J. and Jowitt, P. 2002. Technologies and their influence on future UK marine resource development and management. Marine Policy, 26, 231-241

Smith, H.D. Maes, F. Stojanovic, T.A. and Ballinger, R.C. in press. The integration of land and marine spatial planning. Journal of Coastal Conservation 
Stojanovic, T. and Barker, N. 2008. Improving Governance through local Coastal Partnerships in the UK. Geographical Journal, 174 (4) 344-360.

Tay Estuary Forum, 2009. Management Plan: Tay Estuary and Adjacent Coastline 2009-2014. University of Dundee: Dundee.

UNCED, 1992. Chapter 17: Protection of the oceans, all kinds of seas, and coastal areas. Agenda 21. United Nations Conference on Environment and Development, Rio June 1992 United Nations Rio de Janeiro

Williams E, Firn JR, Kind V, Roberts M and McGlashan DJ 2003 The value of Scotland's ecosystem services and natural capital European Environment 13 67-78

i AGMACS included Working Groups on: (1) Science, Research and Performance Indicators and (4) Marine Nature Conservation.

ii See Scottish Parliamentary debate of 26 October 2006.

iii The development of an ecosystem approach places significant requirements on advancing marine science, especially for the purpose of quantifying impacts on marine ecosystems, in the marine environment which is less well monitored and more challenging to observe. 